Available online at GSC Online Press Directory

GSC Advanced Research and Reviews e-ISSN: 2582-4597, CODEN (USA): GARRC2

Journal homepage: https://www.gsconlinepress.com/journals/gscarr

(RESEARCH ARTICLE)

\title{
Suicidal behavior is four times more frequent in university students with bipolar disorder assessed by an online version of Mood Disorder Questionnaire
}

Luiz Henrique Costa Neto, Kévia Maria Rodrigues de Sousa, Aliny Hellen Lima Pinheiro, Dhynne Kelley Lima de Menezes, Samara Fonseca Frota, Luísa Weber Bisol and Fabio Gomes de Matos e Souza*

Walter Cantídio University Hospital, Fortaleza, Ceará, Brazil.

Publication history: Received on 11 October 2020; revised on 24 October 2020; accepted on 27 October 2020

Article DOI: https://doi.org/10.30574/gscarr.2020.5.1.0086

\begin{abstract}
Introduction: Bipolar disorder (BD) in young people is frequently associated with suicidal behavior. The main objective of this research is to evaluate if university students who have BD show more suicidal behavior than those who do not have BD.

Materials and Methods: 583 university students from Fortaleza, Brazil, participated in this study. Volunteers over 18 years of age who were attending public or private universities from March to December 2019 were able to participate. A sociodemographic and clinical questionnaire and the Mood Disorder Questionnaire (MDQ) were filled out. According to MDQ, participants were classified into three groups: 1) individuals without BD (n=318); 2) individuals with subthreshold BD symptoms ( $\mathrm{n}=160) ; 3)$ individuals with BD $(\mathrm{n}=105)$.
\end{abstract}

Results: Compared to those who do not have BD, individuals with BD had four times less plans for the future $\left(x^{2}=16.00\right.$; $p=0.000)$, considered four times life less worth living $\left(x^{2}=13.44 ; p=0.001\right)$, assumed two times more frequently death as welcome if it comes $\left(x^{2}=19.10 ; p=0.000\right)$, thought two times more about getting hurt $\left(x^{2}=75.32 ; p=0.000\right)$, had seven times more specific plans to die $\left(x^{2}=39.93 ; p=0.000\right)$ and had four times more suicide attempts $\left(x^{2}=33.50 ; p=0.000\right)$.

Conclusions: Suicidal behavior was four times more prominent in university students with BD than in those who did not have BD.

Keywords: Suicide Risk; Bipolar Disorder; University Students; Self-Injurious Behavior; Attempted Suicide.

\section{Introduction}

Worldwide, suicide is considered the second leading cause of death among young people aged from 15 to 29 years [1]. At universities, about $8 \%$ of students who study full time report experiencing suicidal thoughts [2]. In university students, it is also considered the second cause of death [3].

Suicidal behavior consists of three main aspects: 1) suicidal ideation, which are thoughts about taking one's own life; 2) suicide plan, which refers to the formulation of a specific plan for which one intends to die; 3) suicide attempt, which consists of executing potentially harmful behavior, in which there is at least some intention of dying [4]. Suicide or complete suicide occurs when a suicidal act ends up resulting in the individual's death [5].

\footnotetext{
* Corresponding author: Fabio Gomes de Matos e Souza, Cell phone: +5585991714770; E-mail: fgmsouza@yahoo.com.br Walter Cantídio University Hospital, Fortaleza, Ceará, Brazil. 
In Brazil, in 2007, it was found that the suicide rate in young people reached 5.4 per 100,000 inhabitants [2]. In 2019, there were 629 deaths by suicide in the State of Ceará for a population of 9.1 million inhabitants, therefore a rate of 6.9 per 100,000 [6]. One hundred and one of them were reported in the city of Fortaleza [6,7], while 25 (24.75\%) of these were 20 to 29 years old [7]. These numbers may be even higher due to the underreporting of cases, which is a problem in Brazil due to shame and associated taboo, in addition to the possibility of loss of rights and benefits due to the illegality of this type of death $[8,9]$.

The presence of mental disorders can be considered a very important risk factor for suicide. [10] When suicidal behavior is related to bipolar disorder (BD), for example, the risk of death may become more prominent. BD is considered a severe mental disorder and it may be associated with a higher risk of premature mortality, with suicide being one of the main causes. Throughout life, patients with BD are at risk of suicide of around $50 \%$ and it is estimated that $11 \%$ to $19 \%$ of them die for this reason [11].

In young people who present this disorder, data are even more alarming, with suicide being considered one of the three most frequent causes of death [12]. History of suicide attempts is a factor that should always be evaluated carefully, as it is the strongest predictor of suicide. Another important risk factor is younger age [13].

The transition of young people to universities is accompanied by changes in their lives that are related to a new routine, such as academic demands (deadlines, exams, presentations) and changes in personal relationships (family, friendships, love) [14]. This transition generates new challenges for some young people, that may result in vulnerabilities to mental disorders and suicidal behavior [15]. In addition to these factors, hopelessness, which can be related to negative life events, including negative beliefs and expectations about the future, can also be considered to increase the risk of suicide $[16,17]$.

Given the reported data, specific research on the mental health of these students is necessary, since, each year, more young people enter universities. In the United States (USA), the number of enrollments in colleges was 19.8 million in 2017 [18]. In Brazil, in 2018, higher education grew at a rate of 3.6\% per year, with more than 8.4 million students enrolled in colleges [19].

Thus, the main objective of this research is to assess whether university students who have BD show more suicidal behavior than university students who do not have BD, by using a Google Forms application with a sociodemographic and clinical questionnaire and an online version of the Mood Disorder Questionnaire (MDQ).

\section{Material and methods}

\subsection{Sample}

This is a cross-sectional analytical research which was performed from March to December 2019 (Figure 1). Initially, 637 university students answered the questionnaires. However, 54 of them were excluded from the analysis because they met exclusion criteria. Therefore, our sample consisted of 583 university students from the city of Fortaleza, Ceará, Brazil. All of them were over 18 years of age who attended public or private universities.

According to the last survey by the Brazilian Government Data Institute, there were 102,929 university students in Fortaleza [20]. Using the sample size calculator and applying a 95\% confidence level and a confidence interval of 4 , a minimum sample of 597 students was required for the survey [21].

The inclusion criteria were: 1) university students over the age of 18 years; 2) university students from any city in Brazil currently studying in Fortaleza; 3) current students or who have not locked up enrollment in the past two years; 4) students who agreed to participate through the consent form.

The exclusion criteria were: 1) participants who did not authorize the disclosure of their data in the research; 2) students from Fortaleza enrolled in universities located in another city; 3) students from other cities in Brazil who do not study in Fortaleza; 4) post graduate students; 5) participants who did not sign the consent form; 6) participants who did not inform their course; 7) participants who were taking more than one course at the same time. 


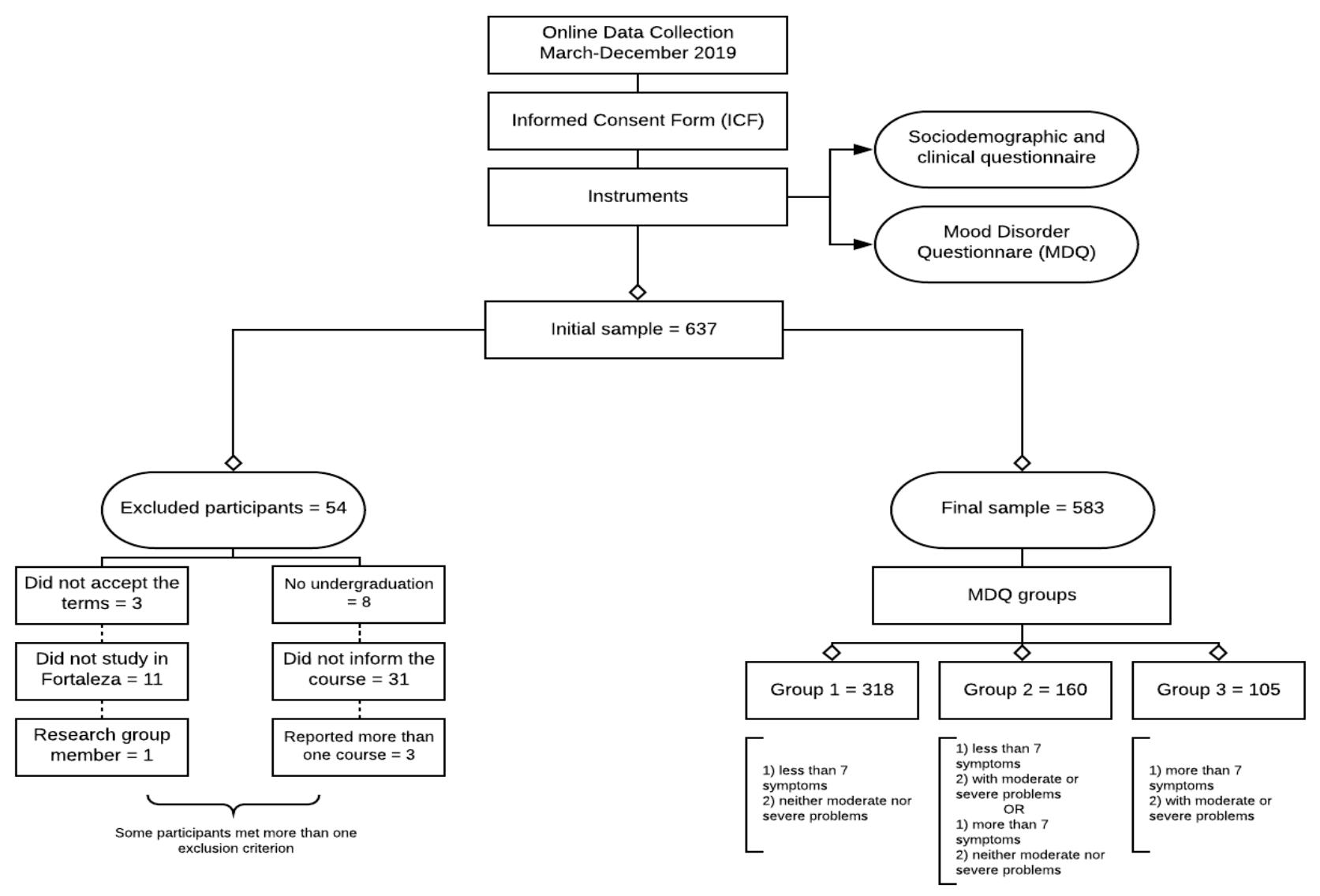

Figure 1 Data collection flowchart.

\subsection{Measures}

Participants answered a sociodemographic and clinical questionnaire containing 40 questions to obtain data such as gender, age, marital status and if they had a part time occupation, as well as questions about suicidal behavior from the PRAVIDA (For Life) Scale, based on a booklet of information on suicide for mental health professionals and society. This scale contains six fundamental items that may be asked in clinical care. The first three questions assess hopelessness, while the last three ones evaluate suicidal ideation, suicide plan and suicide attempt. In addition, it was used one question about family history of suicide [22,23].

They were then invited to complete a Brazilian Portuguese version of MDQ, which has a performance comparable to that of other languages, demonstrating to be a viable and reliable screening instrument [24]. MDQ in an online format was used in order to reach more students, since internet use is increasing worldwide [25,26].

MDQ is a short, one-page self-report bipolar disorder screening instrument that is divided into three sections. The first section includes 13 yes/no questions derived from the DSM-IV criteria and clinical experience. The second part evaluates if the symptoms occurred in the same time period. The third part examines the disability. Positive screening for BD requires 7 or more positive symptoms to be reported within the same time period and causing moderate to severe problems [27]. It can correctly identify 7 out of 10 patients with BD, while 9 out of 10 patients without BD will be correctly eliminated [28], therefore it has high sensitivity and high specificity [27].

\subsection{Procedure}

Data were collected through a Google Form application that can be accessed by computers, tablets and smartphones, which permit tabulation of research data in a fast, easy and secure way [29]. The link to answer the questionnaires was available for ten months to the academic centers of the universities in Fortaleza, and they were passed on to students of various courses. In addition, social networks Facebook and WhatsApp were also used for dissemination. 
According to MDQ results, participants were then classified into three groups: 1 ) individuals without BD (n=318); 2) individuals with subthreshold BD symptoms $(n=160) ; 3)$ individuals with BD $(n=105)$. Group 1 refers to those who reported less than 7 symptoms and did not have moderate or severe problems, thus they do not present BD. Group 2 included a) individuals who reported less than 7 symptoms, but had moderate or severe problems and b) individuals who reported 7 or more symptoms, but did not have moderate or severe problems. Considering these results, these volunteers may present subthreshold BD symptoms. Group 3 was composed of participants who reported more than 7 symptoms and also had moderate or severe problems, therefore presenting higher probability to have BD. In this research, we will consider group 3 as individuals with BD [25].

\subsection{Statistical analysis}

Data were analyzed using Statistical Package for the Social Sciences (SPSS) version 22. Chi-square test (x2) was used to compare the three groups. Statistical significance was considered when p was less than or equal to 0.05 bicaudate.

\subsection{Ethics}

This research was approved by the ethics committees of the Walter Cantídio University Hospital and the Federal University of Ceará. Participation in the study required the student's approval by signing a consent form. Prior to any questionnaire response, the volunteer was required to sign the consent form so that all information provided through the questionnaire responses would only be sent if the student had signed the form. The participants were assured of the confidentiality of the information, in which the possibility of risk to the participant was minimal. In addition, university students did not receive any form of payment, in cash or in benefits, or any other material objects after participating in the research.

Volunteers would be informed by email about their MDQ results. Subjects who have fulfilled criteria for BD would be posteriorly interviewed for application of Mini International Neuropsychiatric Interview (MINI). If a BD diagnosis was made, they would be offered assessment and treatment if necessary.

\section{Results and discussion}

\subsection{Sociodemographic data related to university students with bipolar disorder}

Sociodemographic data are shown in Table 1. Most of the subjects were women $(n=448 ; 76.8 \%)$, from 18 to 21 years old $(n=263 ; 45.1 \%)$, single $(n=487 ; 83.5 \%)$ and students only $(n=497 ; 85.2 \%)$. Group 1 (participants who did not have BD) was the only group that did not show statistical significance in relation to marital status, which could indicate that university students are more likely to present BD (groups 2 and 3 ) and get married earlier ( $\mathrm{x} 2=11.34$ and $\mathrm{p}=0.023$ for group 2; $\mathrm{x} 2=10.74$ and $\mathrm{p}=0.030$ for group $3 ; \mathrm{x} 2=19.16$ and $\mathrm{p}=0.014$ for all groups). Due to the low number of responses $(\mathrm{n}=9 ; 1.6 \%)$ from Divorced/Separated, Widow(er) and those who did not answer marital status categories, we chose to leave Others in the Table. There was no significant correlation with age or occupation.

\subsection{Sociodemographic data related to suicidal behavior in university students}

Tables 2 and 3 show sociodemographic data according to suicidal behavior. University students who were from 18 to 21 and from 22 to 30 years old considered that death would be welcome if it comes more frequently compared to individuals who were more than 30 years old ( $35.4 \%$ and $31.5 \%$ versus $19.4 \%$, respectively; $x 2=6.63 ; p=0.036$ ). College students who were from 18 to 21 and from 22 to 30 years reported having thought about getting hurt or doing harm to themselves or dying more frequently than those who were more than 30 years old $(61.6 \%$ and $56.5 \%$ versus $40.3 \%$, respectively; $\mathrm{x} 2=10.49 ; \mathrm{p}=0.005)$. These data suggest that younger university students are more prone to present hopelessness and suicidal ideation than older university students.

Compared to university students who declared themselves as married, individuals who reported being single had less plans for the future $(4.3 \%$ versus $3.4 \%$; $2=22.83 ; \mathrm{p}<0.001)$, considered life as less worth living $(7.2 \%$ versus $1.1 \%$; $\mathrm{x} 2=19.83 ; \mathrm{p}=0.001)$ and assumed more death as welcome if it comes (34.3\% versus $19.5 \% ; \mathrm{x} 2=13.31 ; \mathrm{p}=0.010)$. College students who were single reported having specific plans to die or to kill themselves more frequently than those who were married $(10.5 \%$ versus $2.3 \%$; $2=16.48 ; \mathrm{p}=0.002)$. These data indicate that single university students present more hopelessness and suicide plans compared to married university students. Due to the low number of responses $(n=9 ; 1.6 \%)$ from Divorced/Separated, Widow(er) and those who did not answer marital status categories, we chose to leave 'Others' in the Table 2. 
Table 1 Sociodemographic data in total sample and groups according to MDQ: group 1 (individuals without BD), group 2 (individuals with subthreshold BD symptoms) and group 3 (individuals with BD).

\begin{tabular}{|c|c|c|c|c|c|c|c|c|}
\hline & \multirow{2}{*}{$\begin{array}{l}\text { All } \\
\text { participants }\end{array}$} & \multirow{2}{*}{$\begin{array}{l}\text { All groups } \\
\text { Test; } \\
\text { Significance }\end{array}$} & \multicolumn{2}{|l|}{ Group 1} & \multicolumn{2}{|l|}{ Group 2} & \multicolumn{2}{|l|}{ Group 3} \\
\hline & & & $\begin{array}{l}n=318 \\
(\%)\end{array}$ & $\begin{array}{l}\text { Test; } \\
\text { Significance }\end{array}$ & $\begin{array}{l}n=160 \\
(\%)\end{array}$ & $\begin{array}{l}\text { Test; } \\
\text { Significance }\end{array}$ & $\begin{array}{l}n=105 \\
(\%)\end{array}$ & $\begin{array}{l}\text { Test; } \\
\text { Significance }\end{array}$ \\
\hline \multicolumn{9}{|l|}{ Gender } \\
\hline Male & $135(23.2)$ & \multirow[t]{2}{*}{$x^{2}=4.93 ; p=0.085$} & $68(21.38)$ & \multirow[t]{2}{*}{$\mathrm{x}^{2}=1.24 ; \mathrm{p}=0.27$} & $34(21.25)$ & \multirow[t]{2}{*}{$x^{2}=0.45 ; p=0.5$} & $33(31.42)$ & \multirow[t]{2}{*}{$x^{2}=4.92 ; p=0.026$} \\
\hline Female & $448(76.8)$ & & $\begin{array}{l}250 \\
(78.61)\end{array}$ & & $\begin{array}{l}126 \\
(78.75)\end{array}$ & & $72(68.57)$ & \\
\hline \multicolumn{9}{|l|}{ Age } \\
\hline 18 to 21 years old & $263(45.1)$ & \multirow[t]{3}{*}{$x^{2}=5.54 ; p=0.236$} & $\begin{array}{l}135 \\
(42.45)\end{array}$ & \multirow[t]{3}{*}{$x^{2}=3.68 ; p=0.1$} & $82(51.25)$ & \multirow[t]{3}{*}{$\mathrm{x}^{2}=5.22 ; \mathrm{p}=0.074$} & $46(43.80)$ & \multirow[t]{3}{*}{$x^{2}=0.10 ; p=0.95$} \\
\hline 22 to 30 years old & $248(42.5)$ & & $\begin{array}{l}137 \\
(43.08)\end{array}$ & & $65(40.62)$ & & $46(43.80)$ & \\
\hline $\begin{array}{l}\text { More than } 30 \text { years } \\
\text { old }\end{array}$ & $72(12.3)$ & & $46(14.46)$ & & $13(8.12)$ & & $13(12.38)$ & \\
\hline \multicolumn{9}{|l|}{ Marital status } \\
\hline Single & $487(83.5)$ & \multirow[t]{3}{*}{$\begin{array}{l}x^{2}=19.16 \\
p=0.014\end{array}$} & $\begin{array}{l}260 \\
(81.76)\end{array}$ & \multirow[t]{3}{*}{$x^{2}=4.67 ; p=0.32$} & $\begin{array}{l}147 \\
(91.87)\end{array}$ & \multirow[t]{3}{*}{$\begin{array}{l}x^{2}=11.34 \\
p=0.023\end{array}$} & $80(76.19)$ & \multirow[t]{3}{*}{$\begin{array}{l}x^{2}=10.74 \\
p=0.030\end{array}$} \\
\hline $\begin{array}{l}\text { Married/Steady } \\
\text { partner }\end{array}$ & 87 (14.9) & & $54(16.98)$ & & $12(7.5)$ & & $21(20.0)$ & \\
\hline Others & $9(1.6)$ & & $4(1.25)$ & & $1(0.62)$ & & $4(3.8)$ & \\
\hline \multicolumn{9}{|l|}{ Occupation } \\
\hline Employed & $86(14.8)$ & \multirow[t]{2}{*}{$x^{2}=3.49 ; p=0.175$} & $39(12.26)$ & \multirow[t]{2}{*}{$x^{2}=3.44 ; p=0.064$} & $29(18.12)$ & \multirow[t]{2}{*}{$x^{2}=2.00 ; p=0.15$} & $18(17.14)$ & \multirow[t]{2}{*}{$x^{2}=0.58 ; p=0.44$} \\
\hline Students only & $497(85.2)$ & & $\begin{array}{l}279 \\
(87.73)\end{array}$ & & $\begin{array}{l}131 \\
(81.87)\end{array}$ & & $87(82.85)$ & \\
\hline
\end{tabular}


Table 2 Sociodemographic data according to suicidal behavior (hopelessness).

\begin{tabular}{|c|c|c|c|c|c|c|c|c|c|c|}
\hline \multirow[t]{2}{*}{ Suicide questions } & \multirow[t]{2}{*}{ Answers } & \multirow[t]{2}{*}{ Data } & \multicolumn{2}{|l|}{ Gender } & \multicolumn{3}{|l|}{ Age } & \multicolumn{3}{|c|}{ Marital status } \\
\hline & & & Male & Female & 18-21 & $22-30$ & $30+$ & Single & Married & Others \\
\hline \multirow[t]{3}{*}{ Do you have plans for the future? } & No & $\mathrm{n}(\%)$ & $8(5.9)$ & $17(3.8)$ & $12(4.6)$ & $9(3.6)$ & $4(5.6)$ & $21(4.3)$ & $3(3.4)$ & $1(11.1)$ \\
\hline & Yes & $\mathrm{n}(\%)$ & $\begin{array}{l}127 \\
(94.1)\end{array}$ & $\begin{array}{l}431 \\
(96.2)\end{array}$ & $\begin{array}{l}251 \\
(95.4)\end{array}$ & $\begin{array}{l}239 \\
(96.4)\end{array}$ & $\begin{array}{l}68 \\
(94.4)\end{array}$ & $\begin{array}{l}466 \\
(95.7)\end{array}$ & $84(96.6)$ & $8(89.9)$ \\
\hline & & $\begin{array}{l}\text { Test; } \\
\text { Significance }\end{array}$ & \multicolumn{2}{|c|}{$x^{2}=1.15 / p=0.284$} & \multicolumn{3}{|c|}{$x^{2}=0.59 / p=0.744$} & \multicolumn{3}{|c|}{$\mathrm{x}^{2}=22.83 / \mathrm{p}<0.001$} \\
\hline \multirow[t]{3}{*}{ Is life worth living? } & No & $\mathrm{n}(\%)$ & $7(5.2)$ & $30(6.7)$ & $22(8.4)$ & $14(5.6)$ & $1(1.4)$ & $35(7.2)$ & $1(1.1)$ & $1(11.1)$ \\
\hline & Yes & $\mathrm{n}(\%)$ & $\begin{array}{l}128 \\
(94.8)\end{array}$ & $\begin{array}{l}418 \\
(93.3)\end{array}$ & $\begin{array}{l}241 \\
(91.6)\end{array}$ & $\begin{array}{l}234 \\
(94.4)\end{array}$ & $\begin{array}{l}71 \\
(98.6)\end{array}$ & $\begin{array}{l}452 \\
(92.8)\end{array}$ & $86(98.9)$ & $8(89.9)$ \\
\hline & & $\begin{array}{l}\text { Test; } \\
\text { Significance }\end{array}$ & \multicolumn{2}{|c|}{$x^{2}=0.40 / p=0.528$} & \multicolumn{3}{|c|}{$x^{2}=4.98 / p=0.083$} & \multicolumn{3}{|c|}{$x^{2}=19.83 / p=0.001$} \\
\hline \multirow[t]{3}{*}{$\begin{array}{l}\text { If death comes, would it be } \\
\text { welcome? }\end{array}$} & Yes & $\mathrm{n}(\%)$ & $44(32.6)$ & $\begin{array}{l}141 \\
(31.5)\end{array}$ & $93(35.4)$ & $78(31.5)$ & $\begin{array}{l}14 \\
(19.4)\end{array}$ & $\begin{array}{l}167 \\
(34.3)\end{array}$ & $17(19.5)$ & $1(11.1)$ \\
\hline & No & $\mathrm{n}(\%)$ & $91(67.4)$ & $\begin{array}{l}307 \\
(68.5)\end{array}$ & $\begin{array}{l}170 \\
(64.6)\end{array}$ & $\begin{array}{l}170 \\
(68.5)\end{array}$ & $\begin{array}{l}58 \\
(80.6)\end{array}$ & $\begin{array}{l}320 \\
(65.7)\end{array}$ & $70(80.5)$ & $8(89.9)$ \\
\hline & & $\begin{array}{l}\text { Test; } \\
\text { Significance }\end{array}$ & \multicolumn{2}{|c|}{$\mathrm{x}^{2}=0.06 / \mathrm{p}=0.806$} & \multicolumn{3}{|c|}{$x^{2}=6.63 / p=0.036$} & \multicolumn{3}{|c|}{$x^{2}=13.31 / p=0.010$} \\
\hline
\end{tabular}


Table 3 Sociodemographic data according to suicidal behavior (suicidal ideation, suicide plan, suicide attempt and family history of suicide).

\begin{tabular}{|c|c|c|c|c|c|c|c|c|c|c|}
\hline \multirow{2}{*}{$\begin{array}{l}\text { Suicide } \\
\text { questions }\end{array}$} & \multirow[t]{2}{*}{ Answers } & \multirow[t]{2}{*}{ Data } & \multicolumn{2}{|l|}{ Gender } & \multicolumn{3}{|l|}{ Age } & \multicolumn{3}{|c|}{ Marital status } \\
\hline & & & Male & Female & $18-21$ & $22-30$ & $30+$ & Single & Married & Others \\
\hline \multirow{3}{*}{$\begin{array}{l}\text { Have you ever } \\
\text { thought about } \\
\text { getting hurt or } \\
\text { doing harm to } \\
\text { yourself or dying? }\end{array}$} & Yes & n (\%) & $74(54.8)$ & $257(57.4)$ & $162(61.6)$ & $140(56.5)$ & $29(40.3)$ & $284(58.3)$ & $41(47.1)$ & $6(66.7)$ \\
\hline & No & $\mathrm{n}(\%)$ & $61(45.2)$ & $191(42.6)$ & $101(38.4)$ & $108(43.5)$ & $43(59.7)$ & $203(41.7)$ & $46(42.9)$ & $3(33.3)$ \\
\hline & & Test; Significance & \multicolumn{2}{|c|}{$x^{2}=0.28 / p=0.600$} & \multicolumn{3}{|c|}{$x^{2}=10.49 / p=0.005$} & \multicolumn{3}{|c|}{$x^{2}=6.46 / p=0.167$} \\
\hline \multirow{3}{*}{$\begin{array}{l}\text { Do you have any } \\
\text { specific plans to } \\
\text { die or kill } \\
\text { yourself? }\end{array}$} & Yes & $\mathrm{n}(\%)$ & $8(5.9)$ & $46(10.3)$ & $28(10.6)$ & $24(9.7)$ & $2(2.8)$ & $51(10.5)$ & $2(2.3)$ & $1(11.1)$ \\
\hline & No & $\mathrm{n}(\%)$ & $127(94.1)$ & 402 (89.7) & $235(89.4)$ & $224(90.3)$ & $70(97.2)$ & $436(89.5)$ & $85(97.7)$ & $8(89.9)$ \\
\hline & & Test; Significance & \multicolumn{2}{|c|}{$x^{2}=2.33 / p=0.127$} & \multicolumn{3}{|c|}{$x^{2}=4.25 / p=0.119$} & \multicolumn{3}{|c|}{$x^{2}=16.48 / p=0.002$} \\
\hline \multirow{3}{*}{$\begin{array}{l}\text { Have you ever } \\
\text { attempted } \\
\text { suicide? }\end{array}$} & Yes & $\mathrm{n}(\%)$ & $16(11.9)$ & $73(16.3)$ & $39(14.8)$ & $42(16.9)$ & $8(11.1)$ & $73(15.0)$ & $14(16.1)$ & $2(22.2)$ \\
\hline & No & $\mathrm{n}(\%)$ & $119(88.1)$ & 375 (83.7) & $224(85.2)$ & $206(83.1)$ & $64(88.9)$ & $414(85.0)$ & $73(83.9)$ & $7(77.8)$ \\
\hline & & Test; Significance & \multicolumn{2}{|c|}{$x^{2}=1.58 / p=0.208$} & \multicolumn{3}{|c|}{$x^{2}=1.53 / p=0.464$} & \multicolumn{3}{|c|}{$x^{2}=5.81 / p=0.214$} \\
\hline \multirow{3}{*}{$\begin{array}{l}\text { Has anyone in } \\
\text { your family ever } \\
\text { attempted or } \\
\text { committed } \\
\text { suicide? }\end{array}$} & Yes & $\mathrm{n}(\%)$ & $40(29.6)$ & $141(31.5)$ & $75(28.5)$ & $83(33.5)$ & $23(31.9)$ & $152(31.2)$ & $24(27.6)$ & $5(55.6)$ \\
\hline & No & n (\%) & $95(70.4)$ & 307 (68.5) & $188(71.5)$ & $165(66.5)$ & $49(68.1)$ & $335(68.8)$ & $63(72.4)$ & $4(44.4)$ \\
\hline & & Test; Significance & \multicolumn{2}{|c|}{$x^{2}=0.16 / p=0.685$} & \multicolumn{3}{|c|}{$x^{2}=1.49 / p=0.474$} & \multicolumn{3}{|c|}{$x^{2}=6.73 / p=0.151$} \\
\hline
\end{tabular}




\subsection{Suicidal behavior among university students related to bipolar disorder}

Suicidal behavior among university students related to BD are demonstrated in Table 4. Compared to those who do not have BD, subjects with BD had more than four times less plans for the future $(11.4 \%$ versus $2.5 \% ; \mathrm{x} 2=16.00 ; \mathrm{p}=0.000)$. Individuals with $\mathrm{BD}$ also considered four times life less worth living compared to individuals without BD (13.3\% versus $3.5 \% ; \mathrm{x} 2=13.44 ; \mathrm{p}=0.001)$. University students with $\mathrm{BD}$ assumed two times more frequent death as welcome if it comes (47.6\% versus $25.2 \% ; \mathrm{x} 2=19.10 ; \mathrm{p}=0.000)$.

Table 4 Suicidal behavior according to MDQ: group 1 (individuals without BD), group 2 (individuals with subthreshold BD symptoms) and group 3 (individuals with BD).

\begin{tabular}{|c|c|c|c|c|}
\hline \multirow[t]{2}{*}{ Suicide questions } & Group 1 & Group 2 & Group 3 & \multirow{2}{*}{$\begin{array}{l}\text { Test; } \\
\text { Significance }\end{array}$} \\
\hline & n (\%) & n (\%) & n (\%) & \\
\hline \multicolumn{4}{|l|}{ Do you have plans for the future? } & \multirow{3}{*}{$\begin{array}{l}x^{2}=16.00 \\
p<0.001\end{array}$} \\
\hline No & $8(2.5)$ & $5(3.1)$ & $12(11.4)$ & \\
\hline Yes & $310(97.5)$ & $155(96.9)$ & $93(88.6)$ & \\
\hline \multicolumn{4}{|l|}{ Is life worth living? } & \multirow{3}{*}{$\begin{array}{l}x^{2}=13.44 \\
p=0.001\end{array}$} \\
\hline No & $11(3.5)$ & $12(7.5)$ & $14(13.3)$ & \\
\hline Yes & $307(96.5)$ & $148(92.5)$ & $91(86.7)$ & \\
\hline \multicolumn{4}{|l|}{ If death comes, would it be welcome? } & \multirow{3}{*}{$\begin{array}{l}x^{2}=19.10 \\
p<0.001\end{array}$} \\
\hline No & $238(74.8)$ & $105(65.6)$ & $55(52.4)$ & \\
\hline Yes & $80(25.2)$ & $55(34.4)$ & $50(47.6)$ & \\
\hline \multicolumn{4}{|l|}{$\begin{array}{l}\text { Have you ever thought about getting hurt or doing harm to } \\
\text { yourself or dying? }\end{array}$} & \multirow[t]{3}{*}{$\begin{array}{l}x^{2}=75.32 \\
p<0.001\end{array}$} \\
\hline No & $187(58.8)$ & $49(30.6)$ & $16(15.2)$ & \\
\hline Yes & $131(41.2)$ & $111(69.4)$ & $89(84.8)$ & \\
\hline \multicolumn{4}{|l|}{ Do you have any specific plans to die or kill yourself? } & \multirow{3}{*}{$\begin{array}{l}x^{2}=39.93 \\
p<0.001\end{array}$} \\
\hline No & $307(96.5)$ & $142(88.8)$ & $80(76.2)$ & \\
\hline Yes & $11(3.5)$ & $18(11.3)$ & $25(23.8)$ & \\
\hline \multicolumn{4}{|l|}{ Have you ever attempted suicide? } & \multirow{3}{*}{$\begin{array}{l}x^{2}=33.50 \\
p<0.001\end{array}$} \\
\hline No & $291(91.5)$ & $131(81.9)$ & $72(68.6)$ & \\
\hline Yes & $27(8.5)$ & $29(18.1)$ & $33(31.4)$ & \\
\hline \multicolumn{4}{|l|}{$\begin{array}{l}\text { Has anyone in your family ever attempted or committed } \\
\text { suicide? }\end{array}$} & \multirow[t]{3}{*}{$\begin{array}{l}x^{2}=11.40 \\
p=0.003\end{array}$} \\
\hline No & $227(71.4)$ & $117(73.1)$ & $58(55.2)$ & \\
\hline Yes & $91(28.6)$ & $43(26.9)$ & $47(44.8)$ & \\
\hline
\end{tabular}

Individuals with BD thought two times more about getting hurt or doing harm to themselves or dying compared to those who do not present BD (84.8\% versus 41.2\%; $\mathrm{x} 2=75.32 ; \mathrm{p}=0.000)$. College students with BD had seven times more specific plans to die or to kill themselves than those without BD (23.8\% versus $3.5 \%$; $x 2=39.93 ; p=0.000)$. Besides, individuals with BD had four times more suicide attempts compared to those who did not have BD $(31.4 \%$ versus $8.5 \%$; $\mathrm{x} 2=33.50 ; \mathrm{p}=0.000$ ).

Individuals with $\mathrm{BD}$ also reported that a family member had attempted or committed suicide almost two times more frequently than individuals without $\mathrm{BD}(44.8 \%$ versus $28.6 \% ; \mathrm{x} 2=11.40 ; \mathrm{p}=0.003)$. 


\section{Discussion}

As far as we know, this is the first research to assess suicidal behavior in university students screened for BD by the MDQ. The main finding of this study is that, in this sample, suicidal behavior was four times more prominent in university students with BD than in university students who do not have BD.

\subsection{Hopelessness reported by university students related to bipolar disorder}

Compared to university students who did not have BD, our results showed that university students with BD had less plans for the future, considered life less worth living and assumed more death as welcome if it comes. Hopelessness is an important factor associated with an increased risk of suicide [17]. In Chinese university students, hopelessness was considered a major risk factor for suicidal behavior, while perceiving meaning in life was shown to be a protective factor [30]. In a Hungarian sample, college students experiencing high hopelessness had higher suicidal ideation than those experiencing low hopelessness [31]. A Brazilian study found that, of 1567 nursing students, 181 (11.55\%) of them reported suicide attempts, of which $33.7 \%$ showed signs of hopelessness [32].

\subsubsection{Suicidal behavior reported by university students related to bipolar disorder}

College students with BD had seven times more specific plans to die or to kill themselves when college students who did not have BD were considered. These data call for a more closely follow-up, as if suicide risk is not detected promptly, a tragedy may occur. One hundred and five (18\% of the total 583) university students had a high probability of presenting BD. In this sample, 25 (23.8\%) individuals reported having a suicide plan. This is far greater than a research which identified about $0.9 \%$ of a sample of college students reporting a suicide plan or attempt [33]. A Chilean study with 460 students who received psychological assistance found that $1.3 \%$ of them had suicidal thoughts with a plan in the 6 months prior to the research and, of these, $75 \%$ had a non-recent suicide attempt [34]. It may be inferred that having BD increases significantly the probability of suicide risk.

More than eighty percent $(n=89)$ of university students with BD reported lifetime suicidal ideation. College students with BD were twice as likely to think about getting hurt, causing harm to themselves or dying, compared to students who did not have BD. This is compared with 331 (56.77\%) students that reported having thoughts about getting hurt, doing harm to themselves or dying. Young university students are particularly vulnerable to the development of suicidal thoughts and behaviors [35]. In a Canadian sample, one third of all individuals aged from 18 to 36 years old who attempted suicide and were in treatment at two general hospitals in Montreal were postsecondary students [36].The prevalence of suicidal ideation among university students seems to vary across regions [37]. A study conducted in the United States revealed a prevalence of $12 \%$ of suicidal ideation among college students [33] while about $9.2 \%$ of Chinese university students had suicidal ideation [37]. This indicates a requirement for attention and development of preventive strategies [38].

Finally, about 31.4\% ( $\mathrm{n}=33$ ) of university students who presented BD had already had at least one lifetime suicide attempt. Compared to university students who did not have BD, individuals with BD had four times more suicide attempts. In the general population with BD, there was about $25-50 \%$ of chance of attempting suicide at least once in their lifetime [39]. In general, previous suicide attempt is a predictor for increased risk of suicide [17]. When a BD diagnosis is considered, previous suicide attempts may be considered an even stronger factor associated with future suicide attempts $[40,41]$ and deaths by suicide [41]. Recurrence of self-harming is most likely within 3-6 months of first presentation [17], therefore these students should be frequently assessed to prevent recurrence of suicidal behavior.

\subsubsection{Family history of suicide reported by university students related to bipolar disorder}

Of 105 university students with BD, 47 (44.8\%) reported family history of suicide. Family history for suicide attempts or deaths by suicide was almost twice more common in college students with BD than in college students who did not have BD. Family history of suicide was an important factor related to suicide attempts in patients with BD [40]. Suicide may be considered an escape from an intolerable negative emotional state [42]. Family history of suicide may indicate a genetically inherited or a learned behavior as a way to resolve conflicts [43-45].

Furthermore, family history of suicide seems to be related not only to suicide attempts. A systematic review revealed that family history of suicide was found to have a strong association with suicide deaths in BD [46]. In addition to the university environment, it is important to assess other factors that contribute to suicidal behaviors that may be present in the unique history of each university student [47]. College health providers should consider these risk factors when screening for mental disorders and risk of suicide [33]. Mental health care should be a priority for universities to prevent suicide in students with some kind of vulnerability. 


\subsubsection{Mood Disorder Questionnaire as a useful instrument for screening of bipolar disorder in university students}

MDQ is a useful instrument for screening of BD in university students. It is a relatively short and easy instrument that could be used to identify college students who are most likely to present BD. This may improve long-term prognosis by starting early diagnosis and treatment, possibly avoiding deaths by suicide. Future studies are necessary to assess if there are higher rates of suicidal behavior in university students with a BD diagnosis confirmed by MINI or other structured interviews.

\section{Strengths and limitations}

Our research has some strengths: 1) The required sample was used according to the sample size calculator [21], that is, it represents adequately university students from Fortaleza. 2) Our survey was limited to Fortaleza, which allowed for a certain cultural homogeneity of the sample. However, a survey limited to one city may not be generalized to other students either from Brazil or other countries. 3) Topics such as suicide behavior may be more accurately assessed using self-report instruments [48]. There is a trend that individuals are more honest when fulfilling self-rated scales than in face-to-face interviews, especially if they feel stigmatized or judged about sensitive issues such as suicidality.

The limitations of this study are: 1) Participants may have chosen to answer the questionnaires due to adverse personal experiences and, possibly, a selection bias should be considered. 2) There is a risk of bias in terms of gender distribution, as there are more than triple female students than male, which may be explained by the fact that women are usually more interested in mental health issues. 3) This is a cross-sectional study, therefore we did not evaluate if university students developed suicidal behavior before starting undergraduation. Longitudinal studies should be implemented in order to clarify this topic. 4) MDQ allows screening for BD, but it cannot confirm a diagnosis.

\section{Conclusion}

In this sample, suicidal behavior was four times more prominent in university students with BD than in university students who did not have BD. Therefore, BD symptoms reported by college students may be associated with greater risk of suicidal behavior. These data point to the need to look more closely at the mental health of university students. Furthermore, MDQ is a useful instrument for the screening of BD in university students and it could probably be used in future studies to assess BD in this environment.

\section{Compliance with ethical standards}

\section{Acknowledgments}

The authors thank all volunteers who participated in this study.

\section{Disclosure of conflict of interest}

The authors declare no conflict of interest, financial or otherwise.

\section{Statement of informed consent}

Informed consent was obtained from all individual participants included in the study.

\section{References}

[1] Mortier P, Cuijpers P, Kiekens G, et al. The prevalence of suicidal thoughts and behaviours among college students: a meta-analysis. Psychol Med. 2018; 48(4):554-565.

[2] Miranda IMO, Zeuri E, Tank K, Barbosa JG, Filho NA, Rezende LF. Caracterização da ideação suicida em estudantes universitários. Revista da Universidade Vale do Rio Verde 2018;16(1):1-8.

[3] Center for Disease Control and Prevention. Suicide: Facts at a glance 2015. cited 2020 jul 11. Retrieved from: http://www.cdc.gov/violenceprevention/pdf/suicide-datasheet-a.pdf

[4] Nock MK, Borges G, Bromet EJ, Cha CB, Kessler RC, Lee S. Suicide and suicidal behavior. Epidemiol Rev. 2008; 30(1):133-154. 
[5] Malhi GS, Outhred T, Das P, Morris G, Hamilton A, Mannie Z. Modeling suicide in bipolar disorders. Bipolar Disord. 2018; 20(4):334-348.

[6] Secretaria da Saúde do Estado do Ceará/COVEP - CEREM. Mortalidade no Estado do CEARÁ. Fortaleza; 2020. Cited 2020 Jul 11. Available from: http://extranet.saude.ce.gov.br/tabulacao/deftohtm.exe?sim/obito.def

[7] Prefeitura de Fortaleza. Mortalidade Geral em Fortaleza - SIM-Fortaleza; 2020. Cited 2020 Jul 11. Available from: http://tabnet.sms.fortaleza.ce.gov.br/scripts/deftohtm.exe?Obitoscid.def

[8] Marcolan JF, Silva DA. O comportamento suicida na realidade brasileira: aspectos epidemiológicos e da política de prevenção. Revista M. 2019; 4(7):31-44.

[9] Fraga WS, Massuquetti A, Godoy MR. Determinantes socioeconômicos do suicídio no Brasil e no Rio Grande do Sul. Article presented in: XIX Encontro de Economia da Região Sul. 2016 Jun; Florianópolis, Santa Catarina.

[10] Studdert DM, Zhang Y, Swanson SA, et al. Handgun Ownership and Suicide in California. N Engl J Med. 2020; 382(23):2220-2229.

[11] Bellivier F, Belzeaux R, Scott J, Courtet P, Golmard JL, Azorin JM. Anticonvulsants and suicide attempts in bipolar I disorders. Acta Psychiatr Scand. 2017; 135(5):470-478.

[12] Baethge C, Cassidy F. Fighting on the side of life: a special issue on suicide in bipolar disorder. Bipolar Disord. 2013; 15(5):453-456.

[13] Antypa N, Antonioli M, Serretti A. Clinical, psychological and environmental predictors of prospective suicide events in patients with Bipolar Disorder. J Psychiatr Res. 2013; 47(11):1800-1808.

[14] Ewing L, Hamza CA, Willoughby T. Stressful Experiences, Emotion Dysregulation, and Nonsuicidal Self-Injury among University Students. J Youth Adolesc. 2019; 48(7):1379-1389.

[15] Hill MR, Goicochea S, Merlo LJ. In their own words: stressors facing medical students in the millennial generation. Med Educ Online. 2018; 23(1):1530558.

[16] Hirsch JK, Hall BB, Wise HA, Brooks BD, Chang EC, Sirois FM. Negative life events and suicide risk in college students: Conditional indirect effects of hopelessness and self-compassion [published online ahead of print, 2019 Nov 25]. J Am Coll Health. 2019; 1-8.

[17] Turecki G, Brent DA. Suicide and suicidal behaviour. Lancet. 2016; 387(10024):1227-1239.

[18] National Center for Education Statistics. Digest of Education Statistics: Digest of Education Statistics. Washington, DC: Integrated Postsecondary Education Data System, Institute of Education Sciences, U.S. Department of Education; 2018. Available from: https://nces.ed.gov/programs/digest/d18/index.asp.

[19] Associação Brasileira Mantenedoras de Ensino Superior. Educação Superior no Brasil: Contextos e Perspectivas - Censo Da Educação Superior 2018; 2020. Available from: https://abmes.org.br/abmespesquisas/detalhe/35/educacao-superior-no-brasil-contextos-e-perspectivas-censo-da-educacao-superior2018.

[20] Instituto Brasileiro de Geografia e Estatística. Censo demográfico Available from: https://cidades.ibge.gov.br/xtras/temas.php?lang=\&codmun=230440\&idtema=105\&search=ceara|fortaleza|ce nso-demografico-2010:-resultados-da-amostra-educacao--.

[21] Surveysystem.com. Creative Research Systems, c2012. Available from: https://www.surveysystem.com/sscalc.htm

[22] Associação Brasileira de Psiquiatria. Suicídio: informando para prevenir. Brasília: CFM/ABP, 2014.

[23] Viana DGN, Silva MSP, Júnior SAS. Histórico, epidemiologia e comorbidades do transtorno bipolar. In: Souza FGM, Bisol LW. Transtorno Bipolar: do espectro ao DSM. Premius Gráfica e Editora; 2020; P. 29-63.

[24] de Sousa Gurgel W, Rebouças DB, Negreiros de Matos KJ, Carneiro AH, Gomes de Matos e Souza F; Grupo de Estudos em Transtornos Afetivos Affective Disorders Study Group. Brazilian Portuguese validation of Mood Disorder Questionnaire. Compr Psychiatry. 2012; 53(3):308-312.

[25] do Nascimento JPR, Costa LB, Meneses RL, da Costa Moreno LM, de Matos e Souza FG Is There Any Difference between Bipolar and Non-bipolar Individuals in the Use of Facebook? Bipolar Disord. 2016; 2: 104.

[26] Faries DE, Houston JP, Sulcs EM, Swindle RW. A cross-validation of the provisional diagnostic instrument (PDI4). BMC Fam Pract. 2012; 13:104. Published 2012 Oct 15. 
[27] Hirschfeld RM, Williams JB, Spitzer RL, et al. Development and validation of a screening instrument for bipolar spectrum disorder: the Mood Disorder Questionnaire. Am J Psychiatry. 2000; 157(11):1873-1875.

[28] Hirschfeld RM. The Mood Disorder Questionnaire: A Simple, Patient-Rated Screening Instrument for Bipolar Disorder. Prim Care Companion J Clin Psychiatry. 2002; 4(1):9-11.

[29] Mathias SLM, Sakai C. Utilização da ferramenta Google Forms no processo de avaliação institucional: estudo de caso nas faculdades magsul. Article presented in: Seminários Regionais; Available from: http://download.inep.gov.br/educacao_superior/avaliacao_institucional/seminarios_regionais/trabalhos_regia o/2013/centro_oeste/eixo_1/google_forms_processo_avaliacao_instit_estudo_caso_faculdades_mag.pdf

[30] Lew B, Huen J, Yu P, et al. Associations between depression, anxiety, stress, hopelessness, subjective well-being, coping styles and suicide in Chinese university students. PLoS One. 2019; 14(7):e0217372. Published 2019 Jul 1.

[31] Chang EC. Hope and hopelessness as predictors of suicide ideation in Hungarian college students. Death Stud. $2017 ; 41(7): 455-460$.

[32] de Albuquerque RN, da Silva Borges M, Monteiro PS. Epidemiological profile of suicidal behavior among nursing students. UERJ Nursing Journal. 2019; 27:45607.

[33] Wilcox HC, Arria AM, Caldeira KM, Vincent KB, Pinchevsky GM, O'Grady KE. Prevalence and predictors of persistent suicide ideation, plans, and attempts during college. J Affect Disord. 2010; 127(1-3):287-294.

[34] Micin S, Bagladi V. Salud Mental en Estudiantes Universitarios: Incidencia de Psicopatología y Antecedentes de Conducta Suicida en Población que Acude a un Servicio de Salud Estudiantil. Terapia Psicológica. 2011; 29(1):5364 .

[35] O'Neill S, McLafferty M, Ennis E, et al. Socio-demographic, mental health and childhood adversity risk factors for self-harm and suicidal behaviour in College students in Northern Ireland. J Affect Disord. 2018; 239:58-65.

[36] Rahme E, Low NC, Lamarre S, et al. Attempted Suicide Among Students and Young Adults in Montreal, Quebec, Canada: A Retrospective Cross-Sectional Study of Hospitalized and Nonhospitalized Suicide Attempts Based on Chart Review. Prim Care Companion CNS Disord. 2015; 17(5):10.4088/PCC.15m01806. Published 2015 Oct 29.

[37] Zhai H, Bai B, Chen L, et al. Correlation between family environment and suicidal ideation in university students in China. Int J Environ Res Public Health. 2015; 12(2):1412-1424. Published 2015 Jan 27.

[38] Torres AR, Campos LM, Lima MCP, Ramos-Cerqueira ATA. Suicidal Ideation Among Medical Students: Prevalence and Predictors. J Nerv Ment Dis. 2018; 206(3):160-168.

[39] Marangell LB, Bauer MS, Dennehy EB, et al. Prospective predictors of suicide and suicide attempts in 1,556 patients with bipolar disorders followed for up to 2 years. Bipolar Disord. 2006; 8(5 Pt 2):566-575.

[40] Schaffer A, Isometsä ET, Azorin JM, et al. A review of factors associated with greater likelihood of suicide attempts and suicide deaths in bipolar disorder: Part II of a report of the International Society for Bipolar Disorders Task Force on Suicide in Bipolar Disorder. Aust N Z J Psychiatry. 2015; 49(11):1006-1020.

[41] Carvalho AF, Firth J, Vieta E. Bipolar Disorder. N Engl J Med. 2020; 383(1):58-66.

[42] Wang S, Jing H, Chen L, Li Y. The Influence of Negative Life Events on Suicidal Ideation in College Students: The Role of Rumination. Int J Environ Res Public Health. 2020; 17(8):2646. Published 2020 Apr 12.

[43] Roy B, Dwivedi Y. Understanding epigenetic architecture of suicide neurobiology: A critical perspective. Neurosci Biobehav Rev. 2017; 72:10-27.

[44] Cha CB, Franz PJ, M Guzmán E, Glenn CR, Kleiman EM, Nock MK. Annual Research Review: Suicide among youth - epidemiology, (potential) etiology, and treatment. J Child Psychol Psychiatry. 2018; 59(4):460-482.

[45] Braga LL, Dell'Aglio DD. Suicídio na adolescência: fatores de risco, depressão e gênero. Contextos Clínicos. 2013; 6(1):2-14.

[46] Schaffer A, Isometsä ET, Tondo L, et al. International Society for Bipolar Disorders Task Force on Suicide: metaanalyses and meta-regression of correlates of suicide attempts and suicide deaths in bipolar disorder. Bipolar Disord. 2015; 17(1):1-16.

[47] da Silva MVM, Azevedo AKS. Um olhar sobre o Suicídio: vivências e experiências de estudantes universitários. Revista Psicologia, Diversidade e Saúde. 2018; 7(3):390-401. 
GSC Advanced Research and Reviews, 2020, 05(01), 030-042

[48] Davison B, Liddle R, Fitz J, Singh GR. Computerised emotional well-being and substance use questionnaires in young Indigenous and non-Indigenous Australian adults. SAGE Open Med. 2020; 8:2050312120906042. Published 2020 Feb 7. 